\title{
Środowiskowe zasoby lokalne czynnikiem potencjalnego sukcesu gospodarczego rejonu wsi Rogóźno (powiat zgierski)
}

\section{Environmental local resources as a factor of potential economic success in Rogóźno (the Zgierz county)}

\section{Michał GÓRECKI}

Uniwersytet Łódzki

Wydział Nauk Geograficznych, Pracownia Geologii

ul. Narutowicza 88, 90-139 Łódź

michal.gorecki@unilodz.eu

Zarys treści: W artykule scharakteryzowano rejon wsi Rogóźno, położonej na północny wschód od Łodzi w powiecie zgierskim, jako obszar perspektywiczny do osiągnięcia sukcesu gospodarczego w oparciu o środowiskowe zasoby lokalne. Zasoby występujące w północnej części gminy Zgierz mogą stać się impulsem rozwojowym zarówno okolic Rogóźna, jak i całego regionu łódzkiego. Mnogość dóbr środowiskowych stwarza z kolei ryzyko pojawienia się sytuacji konfliktowych. Wykorzystanie zasobów wysadu solnego oraz wód mineralnych, termalnych i leczniczych stoi w opozycji do eksploatacji pokładów węgla brunatnego. Niska świadomość opinii publicznej przejawia się syndromem NIMBY w stosunku do planowanych inwestycji.

Słowa kluczowe: zasoby lokalne, sukces gospodarczy, Rogóźno.

\section{Wprowadzenie}

Układ lokalny cechuje się określonym zestawem uwarunkowań rozwojowych zarówno endogenicznych (poziomem infrastruktury technicznej i społecznej, położeniem w przestrzeni geograficznej, elementami środowiska przyrodniczego), jak i egzogenicznych (normami prawnymi, standardami, środowiskiem życia człowieka). Ich jakość oraz stopień wykorzystania decydują o rozwoju lokalnym (Czapiewski 2010). Obszary, na których wpływ uwarunkowań prowadzi do rozwoju, poprawy sytuacji gospodarczej i środowiskowej, a także warunków życia mieszkańców, można zaliczyć do obszarów sukcesu (Bański 2005). Mnogość czynników rozwojowych może również skutkować pojawieniem się sytuacji konfliktowych, gdy rozwój pewnych funkcji ogranicza lub wręcz uniemożliwia rozwój innych (Dmochowska-Dudek 2011).

Jednym z najważniejszych uwarunkowań endogenicznych, które kształtuje procesy społeczno-gospodarcze w niewielkim układzie lokalnym (gminie czy regionie), jest czynnik przyrodniczy. Posiadany wewnętrzny potencjał środowiskowy może być elementem 
składowym wpływającym na procesy rozwojowe gminy (Czapiewski 2010). W skali kraju obszarów predysponowanych do osiągnięcia sukcesu lokalnego opartego na zasobach naturalnych jest niewiele. Jest to zatem czynnik lokalny o zasadniczym znaczeniu, decydujący niekiedy o rozwoju gminy, będący jego bazą rozwojową.

Na obszarze aglomeracji łódzkiej, w wyniku wielowiekowej działalności człowieka, środowisko przyrodnicze ulegało wielostronnym przeobrażeniom zarówno w samym sercu metropolii, jak i na jej peryferiach. Pomimo silnej antropopresji można znaleźć jeszcze tereny posiadające cenne zasoby środowiska naturalnego, które mogą stanowić bazę rozwojową zarówno dla układu lokalnego, jak i regionalnego.

Potencjalnym wiejskim obszarem sukcesu gospodarczego są okolice wsi Rogóźno, położonej na północny wschód od Łodzi w powiecie zgierskim. W podłożu znajdują się pokłady soli kamiennej, węgla brunatnego, a także zasoby wód geotermalnych, mineralnych i leczniczych, mogących stanowić impuls rozwojowy gminy oraz regionu łódzkiego. Budowa geologiczna uniemożliwia osiągnięcie korzyści z jednoczesnej eksploatacji wszystkich złóż. Prowadzi to do pojawiania się lokalnych sytuacji konfliktowych o zróżnicowanej genezie.

Celem niniejszej pracy jest charakterystyka potencjalnego wiejskiego obszaru sukcesu gospodarczego, jakim jest rejon wsi Rogóźno, rozwiniętego w oparciu o naturalne zasoby lokalne oraz ocena możliwości rozwoju lokalnego wynikającego z eksploatacji poszczególnych dóbr w aspekcie środowiskowym oraz społeczno-gospodarczym.

\section{Obszar badań}

Rejon Rogóźna o powierzchni ok. 7800 ha, składa się z 19 sołectw: Astachowice, Bądków, Besiekierz Nawojowy, Besiekierz Rudny, Biała, Brachowice, Celestynów, Dzierżązna, Gieczno, Grabiszew, Jasionka, Kwilno, Lorenki, Rogóźno, Śladków Górny, Warszyce, Władysławów, Wola Rogozińska, Wypychów (ryc. 1), w których w 2011 r. zameldowanych było 3510 osób (https://bdl.stat.gov.pl). Zabudowa zagrodowa i jednorodzinna strefy rolniczej przeplata się tu z urbanizującą się strefą rekreacyjną oraz zabudową jednorodzinną. W krajobrazie dominują pola uprawne, nieużytki oraz lasy (Bald i in. 2011; Krysiak 2014). Pod względem morfologicznym teren jest mało urozmaicony. Na przeważającym obszarze występują równiny stożków napływowych oraz równiny rozlewiskowo-jeziorne, łagodnie nachylone w kierunku głównych rzek rejonu - Moszczenicy oraz Czerniawki (Klatkowa 1993). 


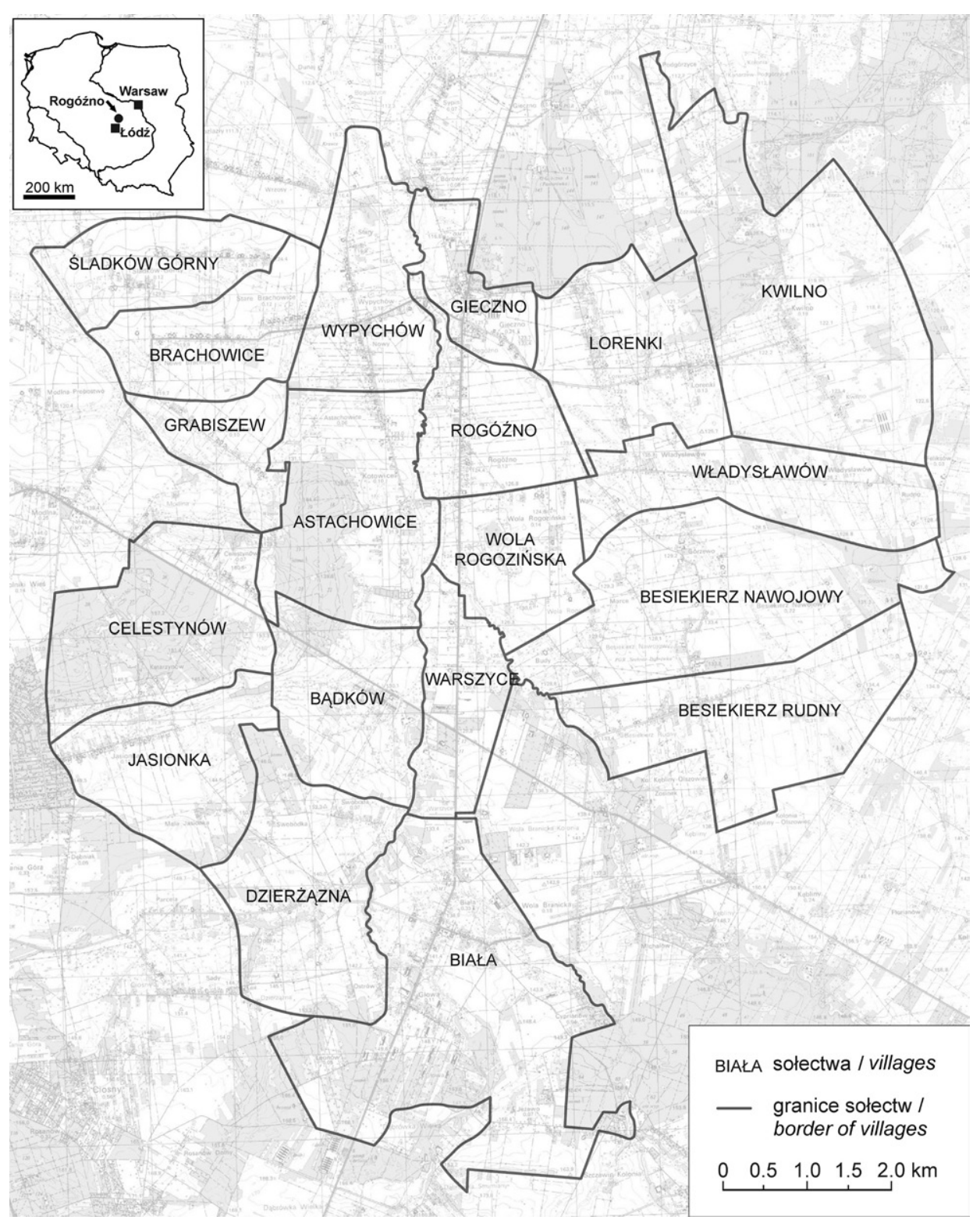

Ryc. 1. Obszar Rogóźna i terenów otaczających

Źródło: opracowanie własne na podstawie: http://www.gmina-zgierz.pl/home/solectwa; mapa topograficzna 1:25 000 arkusze: Ozorków (112.41), Głowno (112.42), Piątek (112.23), Bielawy (112.24).

Rogóźno and surrounding areas

Source: own study based on: http://www.gmina-zgierz.pl/home/solectwa; sheets of topographic map at scale 1:25 000: Ozorków (112.41), Głowno (112.42), Piątek (112.23), Bielawy (112.24). 


\section{Zasoby środowiskowe rejonu Rogóźna}

Rejon Rogóźna posiada cenne i zróżnicowane zasoby środowiska naturalnego, unikalne w skali regionu łódzkiego, mogące stanowić impuls rozwojowy. Należą do nich zarówno zasoby nieodnawialne (pokłady soli kamiennej i węgla brunatnego), jak i odnawialne (wody mineralne, termalne oraz lecznicze, a także pokłady torfów i borowin). Możliwość czerpania korzyści z bogactw środowiska naturalnego dostrzeżono już w latach 50. ubiegłego wieku.

\section{Zasoby nieodnawialne}

W wyniku procesów endo- i egzogenicznych zachodzących w czasie geologicznym utworzyły się w rejonie Rogóźna pokłady soli kamiennej i węgla brunatnego.

Strukturę solną odkryto, poniekąd przypadkowo, podczas badań grawimetrycznych prowadzonych w tym rejonie przed II wojną światową. Po zakończeniu działań wojennych wykonano pierwsze odwierty geologiczne, które dostarczyły informacji o występowaniu w nadkładzie struktury solnej dwóch pokładów węgla brunatnego (Dębski i in. 1963). Początkowo prace badawcze skupiały się na rozpoznaniu złoża chemicznego, jednak z upływem czasu coraz większą uwagę poświęcano złożu energetycznemu. Świadczy o tym m.in. liczba wykonanych odwiertów - informacji o wierzchnich partiach pnia solnego dostarczyło 14 wierceń, natomiast o pokładach węgla brunatnego ok. 240.

Wysad solny Rogóźno jest jednym z największych rozpoznanych ciał solnych na Niżu Polskim. W planie poziomym ma kształt zbliżony do elipsy o wymiarach 6,7 x 4,1 km (Tarka 1992). Zwierciadło solne znajduje się na głębokości 325-427 m p.p.t. (Kasiński i in. 2009). Zasoby bilansowe złoża wynoszą ok. 8,6 mld ton soli (Czapowski i Bukowski 2009), co stanowi ok. 11\% zasobów krajowych (Decyzja Mz z dn. 19.04.2013).

Złoże węgla brunatnego jest dwupokładowe. Dolny pokład charakteryzuje się nieregularnym zaleganiem, w obrębie którego występują zafałdowania i przegięcia. Średnia miąższość tego pokładu wynosi 16,5 metra, maksymalnie 53 m. Występuje na głębokości 170,4-195 m. Węgiel w dolnym poziomie wykazuje duże zasolenie oraz znaczną zawartość siarki. Górny pokład pokrywa większy obszar niż dolny. Jego średnia miąższość wynosi 19,1 m, maksymalnie 44 m. Występuje na głębokości 83,3-100 m. Charakteryzuje się rozszczepieniami na poszczególne ławy węglowe (Stelmaszczyk 1972; Kasztelewicz i Zajączkowski 2011). Łączne zasoby węgla brunatnego oszacowano na ok. 658 mln ton, co pozawala zaliczyć złoże w Rogóźnie do jednych z największych na Niżu Polskim (Kasiński i in. 2009).

\section{Zasoby odnawialne}

Silne zaburzenia tektoniczne, salinarne i glacitektoniczne spowodowały, że struktura solna nie jest szczelnie izolowana od opływających ją wód (Górecki i Ziułkiewicz 2016). W rejonie Rogóźna występują zarówno wody mineralne, termalne oraz lecznicze.

Już od lat 60. XX w. wielu autorów, m.in. Cyryl Kolago, wskazywało na ogromne perspektywy balneologiczne regionu Rogóźna na bazie odkrytych wód mineralnych (Kolago 1965). Specjaliści z zakresu balneoklimatologii, m.in. Henryk Wieliczański, przedstawili opinie kwalifikujące wody z niektórych odwiertów hydrogeologicznych znajdujących się 
po zachodniej i północno-zachodniej stronie wysadu solnego do leczenia szeregu schorzeń: stanów pourazowych, zapalenia nerwów, porażeń i niedowładów, chorób górnych dróg oddechowych, żołądka, itp. W 2013 r. Ministerstwo Zdrowia uznało wodę czerpaną z otworu znajdującego się po zachodniej stronie wysadu (ryc. 2) za wodę leczniczą swoistą 0,9\% chlorkowo-sodową, siarczanową (Decyzja Mz z dn. 19.04.2013). W rejonie Rogóźna stwierdzono także występowanie niewielkich złóż torfów oraz borowin (Kucharski i in. 2013).

\section{Koncepcje wykorzystania naturalnych zasobów lokalnych}

Powstanie i rozwój kompleksu uzdrowiskowo-rekreacyjnego oraz elektrowni geotermalnej związane są z obecnością wysadu solnego i opływających go wód. Z obecnością pokładów węgla brunatnego związana jest natomiast koncepcja utworzenia kombinatu wydobywczo-energetycznego.

\section{Wysad solny oraz wody podziemne}

Wysad solny nigdy nie był obiektem zainteresowania pod względem eksploatacji soli kamiennej. Sama struktura solna może być wykorzystana do podziemnego składowania oraz magazynowania odpadów, gazu ziemnego lub ropy naftowej. Diapir ${ }^{1}$ w Rogóźnie spełnia wymogi techniczne oraz strategiczne stawiane strukturom solnym przeznaczonym do podziemnego magazynowania (Cyran i Garlicki 2008). Wraz z opływającymi go wodami jest ogromnym zasobnikiem energii cieplnej, o wielkości wielokrotnie przekraczającej zapotrzebowanie energetyczne województwa łódzkiego. Energia ta może być czerpana za pomocą instalacji wiertniczych, sięgających głębokości $1250 \div 4000$ m p.p.t., w których krążyć będzie ciecz o temperaturze min. $110^{\circ} \mathrm{C}$, przekazująca na powierzchnię ciepło dla potrzeb produkcji prądu elektrycznego i ciepłej wody. Wytworzona energia mogłaby zasilać projektowane uzdrowisko „Rogóźno” oraz okoliczne miejscowości (Zgierz, Ozorków, Stryków, a w dalszych planach także Łódź). Wykorzystanie energetyczne wysadu polegałoby na wypłukaniu wodą w diapirze kawerny (pustki) i wypełnieniu jej płynem niełączącym się chemicznie z solą, np. benzyną lub ropą. W wymienniku ciepła znajdującym się na powierzchni terenu przepompowywana ciecz, krążąca w obiegu zamkniętym, ogrzewałaby wodę, przekształcając ją w parę wodną, wykorzystywaną do produkcji energii elektrycznej, a ciepło odpadowe posłużyłoby potrzebom lokalnym uzdrowiska. Aby nie naruszyć budowy geologicznej - według koncepcji - w wysadzie solnym można wykonać

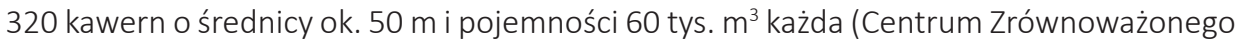
Rozwoju 2008).

Występowanie wód termalnych, mineralnych oraz leczniczych należy wiązać z ciałem solnym. Dwukrotnie podejmowane były próby powołania społecznego komitetu budowy w Rogóźnie uzdrowiska, jednak nie zostały one zrealizowane (Stelmaszczyk 1972). Od lat 70. temat ten został porzucony na kolejnych 40 lat. W 2013 r. Ministerstwo Zdrowia ustanowiło obszar ochrony uzdrowiskowej „Rogóźno” obejmujący 14 sołectw w gminie Zgierz oraz jedno w gminie Ozorków. Dla strefy uzdrowiskowej ustalono kierunki leczenia chorób

\footnotetext{
${ }^{1}$ diapir; diapir solny - synonim terminu „wysad solny”
} 
ortopedyczno-urazowych, reumatologicznych oraz dolnych i górnych dróg oddechowych (Decyzja MZ z dn. 19.04.2013). Kompleks uzdrowiskowo-rekreacyjny ma bazować na wodzie pobieranej z otworu znajdującego się po zachodniej stronie wysadu. Dodatkowo, poza lecznictwem wodnym, perspektywiczne jest również wykorzystanie borowin (torfów). W myśl decyzji przewiduje się budowę w strefie „A" sanatorium, Domu Zdrojowego, inhalatorium otwartego $w$ formie tężni solankowych oraz basenu rehabilitacyjnego. W otaczającej ją i znacznie rozleglejszej strefie „B” (ryc. 2) i „C" ochrony uzdrowiskowej, stanowiącej zaplecze gospodarcze uzdrowiska, planuje się utworzyć obiekty sportowe i turystyczne - tzw. Centrum Rekreacji, Wypoczynku i Rozrywki. Jednak w sierpniu 2015 r. zgodnie z uchwałą zatwierdzoną przez gminę Ozorków o podziale sołectwa Celestynów na dwa sołectwa: Celestynów i Katarzynów, konieczne jest wytyczenie nowej granicy dla strefy "C" ochrony uzdrowiskowej przebiegającej po granicach administracyjnych. Oznacza to wycofanie projektu rozporządzenia Rady Ministrów z dalszych prac legislacyjnych i przygotowanie nowego operatu uzdrowiskowego, uwzględniającego stosowne korekty (https://bip.kprm.gov.pl/).

\section{Węgiel brunatny}

Pokłady węgla brunatnego są przedmiotem zainteresowania Zespołu Elektrociepłowni Pątnów, Adamów, Konin (PAK). Rejon Rogóźna jest dla PAK terenem możliwej lokalizacji elektrowni w oparciu o odkrywkową kopalnię węgla (Tynenski i in. 2007). Ze względu na zbyt małą głębokość zalegania złoża, niekorzystne warunki tektoniczne oraz niekorzystne usytuowanie wobec poziomów wodonośnych, nie można przeprowadzić podziemnego zgazowania węgla. Istnieje natomiast możliwość zgazowania wydobytego węgla na powierzchni (Kasztelewicz i Zajączkowski 2011). Jedynym jak do tej pory udostępnionym materiałem przedstawiającym koncepcję zagospodarowania rejonu Rogóźna pod odkrywkową kopalnię węgla jest zacytowany powyżej artykuł Kasztelewicza i Zajączkowskiego z 2011 r. W opracowanej strategii dla zagłębia adamowskiego, do którego przynależne byłoby złoże Rogóźno, wydobycie pierwszej tony węgla z nowej odkrywki przypada na rok 2023. Prace przygotowawcze, polegające na zdejmowaniu skał nadkładu, musiałyby rozpocząć się w roku 2020. Początkowo prace wydobywcze objęłyby wyłącznie górny pokład węgla, ze względu na niekorzystne własności pokładu dolnego (głębokie zaleganie, duże zasolenie i zasiarczenie). We właściwej fazie eksploatacji planuje się wydobywanie $10 \mathrm{mln}$ ton węgla rocznie. Docelową eksploatacją objęty zostałby teren o powierzchni 2235 ha pod wyrobiskiem oraz 570 ha pod zwałowiskiem wewnętrznym (ryc. 3). W konturze docelowego wyrobiska znajdzie się 1,75 $\mathrm{mld} \mathrm{m}^{3}$ nadkładu oraz $325 \mathrm{mln}$ ton węgla, co daje wskaźnik przemysłowy na poziomie 5,4:1 $\mathrm{m}^{3} /$ tonę. Oznacza to, że aby wydobyć 1 tonę węgla, należy usunąć $5,4 \mathrm{~m}^{3}$ skał nadkładu. 


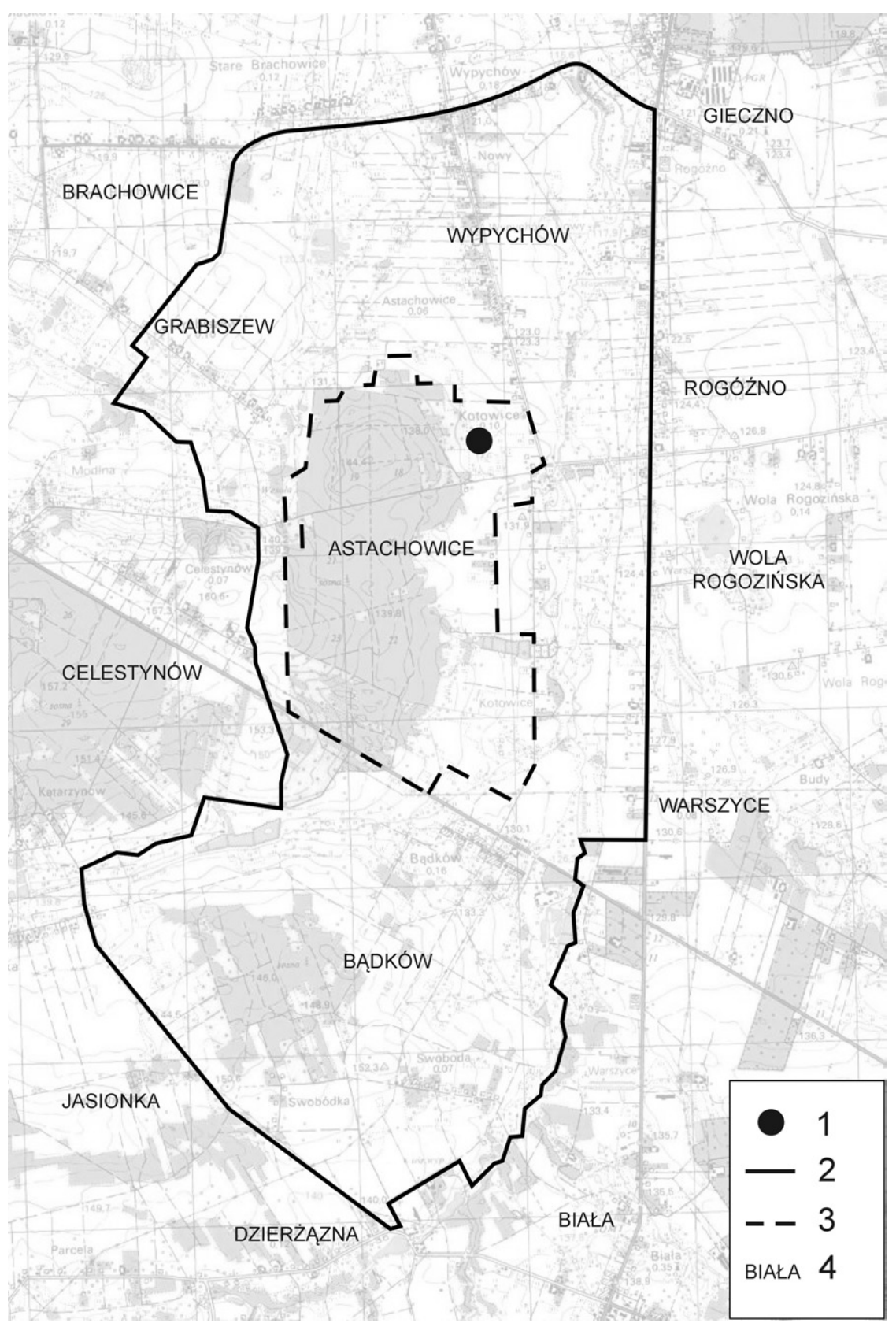

Ryc. 2. Zasięg przestrzenny projektowanej strefy „ $A$ ” i „,B” ochrony uzdrowiskowej

1 - studnia z udokumentowaną wodą leczniczą, 2 - granica strefy ochrony uzdrowiskowej „B”, 3 - granica strefy ochrony uzdrowiskowej „A", 4 - sołectwa.

Źródło: Kucharski i in. (2013), zmienione.

Spatial scope of $A$ and $B$ zones of the health resort protection area

1 - a well with certified therapeutic water, 2 - a border of the health resort protection area $B, 3-a$ border of the health resort protection area $A, 4$-villages.

Source: Kucharski et al. (2013), changed. 


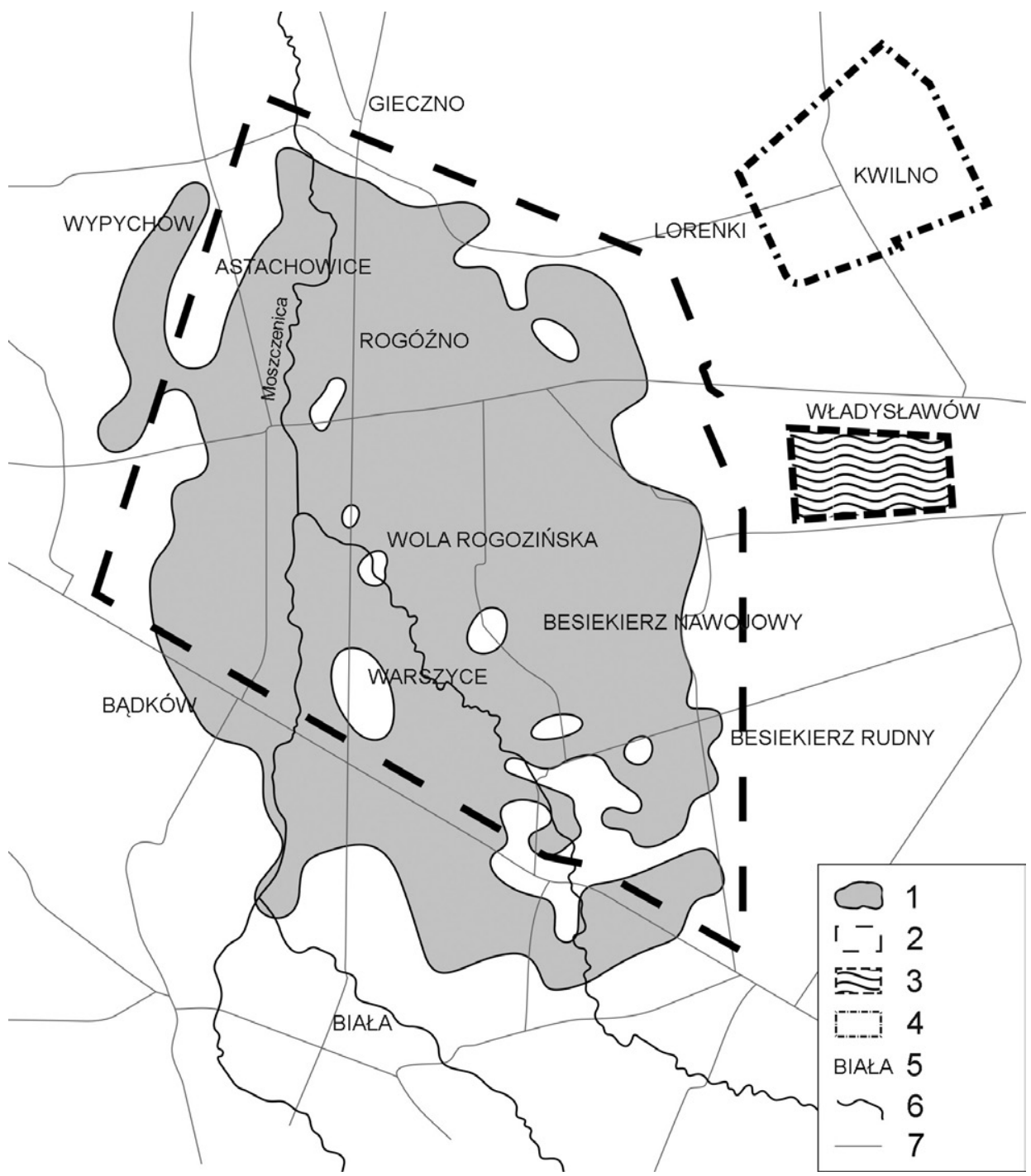

Ryc. 3. Przewidywany zasięg eksploatacji górnego kompleksu węglowego złoża Rogóźno

1 - złoże bilansowe w górnym kompleksie węglowym, 2 - zasięg projektowanego wyrobiska, 3 - elektrownia lub zakład zgazowania węgla, 4 - projektowane zwałowisko zewnętrzne, 5 - sołectwa, 6 - rzeki, 7 - drogi. Źródło: Kasztelewicz i Zajączkowski (2011), zmienione.

Estimated scope of exploitation of the upper lignite deposit in Rogóźno

1 - recoverable deposits in the upper lignite complex, 2 - scope of the planned pit, 3 - power station or coal gasification plant, 4 - planned external spoil tip, 5 - villages, 6 -rivers, 7 -roads.

Source: Kasztelewicz \& Zajączkowski (2011), changed. 


\section{Możliwość osiągnięcia sukcesu gospodarczego przez rejon Rogóźna}

Wykorzystanie lokalnych zasobów środowiskowych może stanowić jednorazowy impuls rozwojowy. W regionie łódzkim surowce naturalne przyczyniły się do osiągnięcia sukcesu gospodarczego w gminie Kleszczów - w oparciu o węgiel brunatny (Bański 2008) oraz w Uniejowie - w oparciu o wody geotermalne (Smętkiewicz 2014). Zasoby lokalne występujące w rejonie Rogóźna również mogą zadecydować o rozwoju gospodarczym zarówno gminy Zgierz, jak i całego regionu łódzkiego (Kasztelan 2010). Należy do nich zaliczyć przede wszystkim bazę surowcową, sąsiedztwo dużego miasta, dobrze rozwiniętą sieć drogową i bliskość węzłów komunikacyjnych (Bański 2008; Feltynowski 2009).

Sukces w wymiarze społecznym oraz gospodarczym, przy jednoczesnej ochronie środowiska, można osiągnąć, realizując koncepcję zrównoważonego rozwoju. Zgodnie z założeniami trwałego rozwoju, dotyczącymi m.in.: zachowania i poprawy stanu zdrowia mieszkańców, długofalowego wykorzystania odnawialnych zasobów naturalnych, utrzymania stabilności procesów ekologicznych i ekosystemów czy ochrony przyrody (Kasztelan 2010), rozwój rejonu Rogóźna należy nakierować w stronę utworzenia uzdrowiska oraz elektrowni geotermalnej. Założenia ekorozwoju można także osiągnąć poprzez efektywną eksploatację nieodnawialnych źródeł energii (Kasztelan 2010), jednak w Rogóźnie jest to niewykonalne (Studium... 1999).

\section{Aspekt środowiskowy}

Utworzenie kombinatu wydobywczo-energetycznego spowoduje powstanie leja depresyjnego o głębokości ok. 200 m oraz zasolenie wód powierzchniowych (Studium... 1999). Głębokie oraz rozległe powierzchniowo wyrobisko przyczyni się do silnej degradacji środowiska przyrodniczego w północnej części województwa łódzkiego. W rejonie Bełchatowa, natrafiając na wysad solny Dębina, dokonano wszelkich starań, aby wody podziemne nie miały styczności ze skałami zasolonymi (Seweryn i in. 2004). W Rogóźnie sytuacja jest zupełnie odmienna. Ługi solne wykazują mineralizację w granicach 304-346 g/dm³ (Lewkiewicz-Małysa i Winid 2005). Wody górnojurajskie, na których drodze przepływu znajduje się wysad w Rogóźnie, zostaną silnie wzbogacone solami. Ich bazą drenażu jest dolina Bzury na północ od Ozorkowa (Bierkowska i Błaszczyk 1989). Wszelkie ujęcia wód jurajskich oraz kredowych znajdujące się na obszarze ich przepływu staną się nieużyteczne. Odkrywkowa kopalnia węgla wymusi również zmianę biegu Moszczenicy oraz, podobnie jak w przypadku Bzury, jej silne zasolenie. Osadniki nie oczyszczą wód dołowych do tego stopnia, aby nie oddziaływały negatywnie na wody powierzchniowe. Woda wypływająca z osadnika przy KWK „Ziemowit” w 2002 r. cechowała się mineralizacją ok. 54 g/dm³ i stężeniem jonów $\mathrm{Cl}^{-}$wynoszącym 29,4 g/dm³ (Jabłońska 2006). Obecnie wody Moszczenicy po wypłynięciu z rejonu Rogóźna zawierają ok. 0,031g/dm³ jonów Cl- (Górecki 2015). Słodkowodne ekosystemy rzeczne Moszczenicy i Bzury, w tym również cenny przyrodniczo obszar Natura 2000 „Pradolina Bzury-Neru”, ulegną degradacji (Kucharski i Kopeć 2014). Duży ładunek substancji zasalających transportowany rzekami spowoduje utratę ich zdolności do samooczyszczania. Przy niewielkiej wówczas modyfikacji parametrów fizyczno-chemicznych z biegiem rzek, zanieczyszczone wody Bzury i Moszczenicy wpłyną do Wisły. Poza negatywnym oddziaływaniem na wody kopalnia przyczyni się również do nieodwracalnych zmian w krajobrazie oraz emisji pyłowo-gazowej. 
Energia wysadu solnego oraz opływających go wód byłaby, w przeciwieństwie do energii czerpanej ze źródła konwencjonalnego jakim jest węgiel brunatny, energią czystą oraz odnawialną (Centrum Zrównoważonego Rozwoju 2008). Jej pozyskiwanie wiąże się jednak z ingerencją w samą strukturę pnia solnego. Bez dokładnych badań geologicznych oraz geofizycznych nie można jednoznacznie stwierdzić, czy tego typu instalacje mają szansę powstać w Rogóźnie. Stosowanie medium w postaci ropy lub benzyny w przypadku awarii stwarza ryzyko zanieczyszczenia i ewentualnego zatrucia środowiska, a w szczególności wód podziemnych. Tektonika solna wespół z odprężeniami wzbudzonymi pracami górniczymi może skutkować niestabilnością budowy geologicznej, i to w aktywnej strefie halokinetycznej². Pozytywne wyniki badań dają jednak ogromne możliwości pozyskiwania odnawialnej energii przy minimalnej ingerencji w krajobraz. Czerpanie wód leczniczych kilkoma odwiertami oraz wybudowanie kompleksu budynków sanatoryjnych i rekreacyjnych nie będzie mocno ingerować w otaczające tereny. Prawidłowe funkcjonowanie uzdrowiska może przyczynić się do poprawy jakości środowiska naturalnego, w tym wód rzecznych.

\section{Aspekt społeczno-gospodarczy}

Obecnie obserwuje się rosnące zainteresowanie turystyką zdrowotną (Herman i in. 2014). Zgodnie z decyzją Ministra Zdrowia z 19.04.2013 r. o uzyskaniu przez rejon Rogóźna statusu obszaru ochrony uzdrowiskowej brak odpowiedniej infrastruktury uzdrowiskowej, składającej się z zakładów i urządzeń lecznictwa (założonej w decyzji Ministra Zdrowia) oraz bardzo słabo rozwinięta infrastruktura wodno-ściekowa w północnej części wiejskiej gminy Zgierz uniemożliwiają na chwilę obecną uzyskanie przez rejon Rogóźna statusu uzdrowiska (Herman i in. 2014; Górecki 2013). W regionie tódzkim konkurencyjną miejscowością kuracyjną są Skierniewice, gdzie prace poczynione w tym zakresie są znacznie bardziej zaawansowane (Herman i in. 2014).

Mnogość środowiskowych zasobów lokalnych występujących w rejonie Rogóźna stanowi swoistą blokadę rozwojową i prowadzi do pojawienia się konfliktu funkcji z walorami przestrzeni (Badera 2010; Dmochowska-Dudek 2011). Wykorzystanie własności bryły solnej oraz cennych wód podziemnych stoi w opozycji do eksploatacji węgla brunatnego. Dodatkowymi czynnikami mogącymi wzmagać sytuacje konfliktowe są: środki finansowe, brak działań władz samorządowych, prawo miejscowe oraz niska świadomość społeczna.

Każda przewidziana inwestycja, zarówno budowa uzdrowiska, elektrowni geotermalnej czy odkrywkowej kopalni węgla brunatnego, wiąże się z dużymi nakładami finansowymi. Budowa i rozwój kompleksu uzdrowiskowo-rekreacyjnego to koszt ok. $182 \mathrm{mln}$ zł (Tynenski i in. 2007). Koszt budowy elektrowni geotermalnej, zaspokajającej potrzeby lokalne i regionalne o mocy ok. 250 MW (8\% zapotrzebowania województwa), bazującej na 10-12 kawernach, wynosi ok. 500 mln zł (Centrum Zrównoważonego Rozwoju 2008). Wydatek kilkuset milionów złotych przewyższa możliwości finansowe gminy. Jednak przy ewentualnym wsparciu prywatnych inwestorów oraz środków z Unii Europejskiej, np. z Europejskiego Funduszu Rozwoju Regionalnego w ramach Regionalnego Programu Operacyjnego Województwa Łódzkiego, Programu Operacyjnego Innowacyjna Gospodarka, czy Programu Operacyjnego Infrastruktura i Środowisko, gmina ma szansę zrealizować te inwestycje.

\footnotetext{
2 halokineza - deformacje struktur skalnych pod wpływem wgłębnych ruchów mas solnych wywołanych ciśnieniem skał nadległych.
} 
W 2010 r. władze samorządowe jednoznacznie wytyczyły kierunek rozwoju rejonu Rogóźna na utworzenie uzdrowiska wraz z całą infrastrukturą leczniczą, rozrywkową oraz technologiczną (Kucharski i in. 2013). Brak dalszych działań, w tym prowadzenia akcji informacyjnych przez władze lokalne, może wynikać z braku miejscowych planów zagospodarowania przestrzennego. Na obszarze wiejskiej gminy Zgierz udział terenów pokrytych miejscowymi planami zagospodarowania przestrzennego w powierzchni całej gminy jest mniejszy niż 20\% (Wójcik i in. 2014). Okolice Rogóźna nie są objęte planami. Oznacza to, że „rejon Rogóźna” nie ma jednoznacznie wytyczonego kierunku rozwojowego. A zatem wszystkie scenariusze inwestycyjne mają szansę na realizację.

Brak planów miejscowych, działań władz samorządowych oraz akcji informacyjnych przyczyniają się do niedostatecznej świadomości społecznej oraz zwiększają ryzyko pojawienia się konfliktów (Wójcik i in. 2014). Miejscowa ludność nie jest informowana o korzyściach oraz zagrożeniach wynikających z realizacji poszczególnych scenariuszy inwestycyjnych, co wpływa na negatywną ocenę opinii publicznej jakichkolwiek działań rozwojowych. Liczne akcje informacyjne prowadzone w Uniejowie przed wybudowaniem uzdrowiska przyczyniły się do wzrostu świadomości społecznej mieszkańców o korzyściach płynących z funkcjonującego kompleksu (Smętkiewicz 2014). Podobne akcje informacyjne prowadzone są w Skierniewicach, gdzie gmina pokłada ogromne nadzieje w uzdrowisku.

Występowanie potencjalnych obszarów konfliktowych, a za taki należy uznać rejon Rogóźna, często prowadzi do pojawienia się realnych konfliktów przestrzennych. Miejscowa ludność prezentuje postawę NIMBY, wyrażając w ten sposób sprzeciw wobec inwestycji „niechcianych” z ich punktu widzenia. Analizując szkodliwość i uciążliwość planowanych inwestycji, zarówno w aspekcie społecznym, jak i środowiskowym, bez wątpienia obiektem NIMBY jest kombinat wydobywczo-energetyczny. Kilkukrotnie, gdy KWB Adamów próbowała rozpocząć wstępne działania inwestycyjne w rejonie Rogóźna, polegające na wykupie ziemi oraz badaniach geologicznych, spotykała się z natychmiastowym oporem mieszkańców. Społeczność lokalna organizowała liczne akcje protestacyjne, manifestacje oraz blokady dróg. Swoją niechęć do utworzenia kopalni wyrażała także poprzez masowe rozwieszanie plakatów „Kopalni-nie! ” (http://lodzkie.naszemiasto.pl).

W wymiarze gospodarczym rozwój rejonu Rogóźna dostarczy wymiernych korzyści. Utworzenie sektora uzdrowiskowego znacznie podniesie rangę i atrakcyjność gminy. Przyczyni się także do poprawy stanu infrastruktury, wykorzystywanej również przez miejscową ludność. Bliskość aglomeracji łódzkiej oraz dobre połączenia drogowe z pozostałymi ośrodkami miejskimi o różnej randze - Łęczyca, Kutno, Łowicz czy nawet Warszawa (Bański 2008; Feltynowski 2009), może zapewnić dużą rzeszę kuracjuszy i turystów. W funkcjonującym obiekcie uzdrowiskowo-rekreacyjnym pracę może znaleźć minimum 1300 osób. Z powstaniem kombinatu wydobywczo-energetycznego wiąże się utworzenie ok. 2000 miejsc pracy (Centrum Zrównoważonego Rozwoju 2008), przy jednoczesnym wysiedleniu co najmniej 1300 osób i likwidacji 9 sołectw (Kasztelewicz i Zajączkowski 2011; https://bdl.stat. gov.pl). Odkrywka wymusi przebudowę oraz rozwój istniejącej sieci infrastrukturalnej. 


\section{Podsumowanie}

Sukces lokalny w rejonie Rogóźna, osiągnięty w oparciu o potencjał wewnętrzny, jakim są bogactwa naturalne, przełożyłby się na sukces finansowy, ekonomiczny oraz infrastrukturalny zarówno gminy Zgierz, jak i regionu łódzkiego. Zamierzony sukces można uzyskać, realizując każdą z zaprezentowanych wizji rozwojowych. Różnią się one stopniem ingerencji w środowisko przyrodnicze oraz społeczno-gospodarczą działalność człowieka. Realizacja któregokolwiek scenariusza inwestycyjnego spowoduje poprawę bądź pogorszenie jakości poszczególnych elementów, przyjmując, że stan obecny traktowany jest jako „0" (tab. 1).

Tabela 1. Potencjalne korzyści oraz straty wynikające z funkcjonowania uzdrowiska (A), elektrowni geotermalnej (B) oraz kombinatu wydobywczo-energetycznego (C) w aspekcie środowiskowym oraz społeczno-gospodarczym

\begin{tabular}{|c|c|c|}
\hline \multirow{2}{*}{ A } & \multicolumn{2}{|c|}{ UZDROWISKO } \\
\hline & aspekt środowiskowy & aspekt społeczno-gospodarczy \\
\hline+ & $\begin{array}{l}\text { - niewielka ingerencja w krajobraz } \\
\text { - poprawa jakości wód powierzchniowych } \\
\text { - poprawa jakości powietrza } \\
\text { - możliwość funkcjonowania wespół z elektrownią } \\
\text { geotermalną (wykorzystującą ten sam zasób } \\
\text { środowiskowy jak uzdrowisko) }\end{array}$ & $\begin{array}{l}\text { - przebudowa i rozbudowa infrastruktury tech- } \\
\text { nicznej i transportowej } \\
\text { - nowe miejsca pracy } \\
\text { - wzrost rangi i atrakcyjności gminy } \\
\text { - zwiększenie dochodów gminy } \\
\text { - alternatywa dla budowy odkrywkowej kopalni } \\
\text { węgla brunatnego }\end{array}$ \\
\hline & \multicolumn{2}{|c|}{$\begin{array}{l}\text { - możliwość dotychczasowego sposobu użytkowania ziemi (prowadzenia działalności rolniczej i trzyma- } \\
\text { nia zwierząt gospodarskich) na terenach poza strefą „ } \mathrm{A}^{\prime \prime} \text { ochrony uzdrowiskowej }\end{array}$} \\
\hline- & $\begin{array}{l}\text { - dodatkowe obciążenie środowiska przyjezdną } \\
\text { ludnością (większa ilość wytwarzanych odpadów, } \\
\text { ścieków, zwiększony ruch samochodowy) } \\
\text { - gospodarowanie zużytymi wodami mineralnymi/ } \\
\text { termalnymi } \\
\text { - budowa dedykowanych instalacji unieszko- } \\
\text { dliwiania ścieków z placówek sanatoryjnych, } \\
\text { medycznych } \\
\text { - zasób wód leczniczych, mineralnych, termal- } \\
\text { nych może być „wyczerpywalny” w przypadku } \\
\text { niewłaściwej eksploatacji lub niedokładnego } \\
\text { oszacowania złoża }\end{array}$ & $\begin{array}{l}\text { - wysokie koszty budowy kompleksu } \\
\text { rekreacyjno-uzdrowiskowego } \\
\text { - wzrost liczby osób przebywających w rejonie } \\
\text { Rogóźna, migracje turystyczne } \\
\text { - prawdopodobna konieczność likwidacji wielko- } \\
\text { powierzchniowych ferm ze względu na odory } \\
\text { i wyziewy „nieprzystające” do otoczenia } \\
\text { uzdrowiska, w tym mogące zawierać substancje } \\
\text { chorobotwórcze }\end{array}$ \\
\hline \multirow[t]{2}{*}{ B } & \multicolumn{2}{|c|}{$\begin{array}{c}\text { ELEKTROWNIA GEOTERMALNA } \\
\text { (ENERGIA WYSADU SOLNEGO I OPŁYWAJĄCYCH GO WÓD) }\end{array}$} \\
\hline & aspekt środowiskowy & aspekt społeczno-gospodarczy \\
\hline+ & $\begin{array}{l}\text { - mała ingerencja w krajobraz } \\
\text { - możliwość czerpania „czystej” energii; } \\
\text { - możliwość funkcjonowania wespół z uzdrowi- } \\
\text { skiem (wykorzystującym ten sam zasób środowi- } \\
\text { - bowy jak geotermia) } \\
\text { - brak emisji pyłowo-gazowej } \\
\text { - możliwość dotychczasowego sposobu użytkowani }\end{array}$ & $\begin{array}{l}\text { - energia relatywnie tańsza niż ze źródeł } \\
\text { konwencjonalnych } \\
\text { - zwiększenie dochodów gminy } \\
\text { - alternatywa dla budowy odkrywkowej kopalni } \\
\text { węgla brunatnego }\end{array}$ \\
\hline- & $\begin{array}{l}\text { - ingerencja w strukturę pnia solnego } \\
\text { - stosowanie medium w postaci ropy lub benzyny, } \\
\text { w przypadku awarii spowoduje zanieczyszczenie } \\
\text { i skażenie wód podziemnych } \\
\text { - zasób energetyczny wód podziemnych może być } \\
\text { „wyczerpywalny” w przypadku niewłaściwej eks- } \\
\text { ploatacji lub niedokładnego oszacowania złoża }\end{array}$ & $\begin{array}{l}\text { - wysokie koszty budowy elektrowni } \\
\text { - konieczność budowy sieci przesyłowej oraz } \\
\text { rozdzielczej }\end{array}$ \\
\hline
\end{tabular}




\begin{tabular}{|c|c|c|}
\hline \multirow[t]{2}{*}{ C } & \multicolumn{2}{|c|}{ KOMBINAT WYDOBYWCZO-ENERGETYCZNY } \\
\hline & aspekt środowiskowy & aspekt społeczno-gospodarczy \\
\hline+ & brak & $\begin{array}{l}\text { - przebudowa i rozbudowa infrastruktury tech- } \\
\text { nicznej i transportowej } \\
\text { - zwiększenie dochodów gminy } \\
\text { - nowe miejsca pracy }\end{array}$ \\
\hline- & $\begin{array}{l}\text { - rozległe i głębokie wyrobisko } \\
\text { - rozległy lej depresji } \\
\text { - nieodwracalne zmiany w krajobrazie } \\
\text { - ograniczoność zasobów } \\
\text { - zmiana biegu rzek } \\
\text { - silne zasolenie wód powierzchniowych } \\
\text { - włączenie do systemu krążenia wód } \\
\text { podziemnych wód silnie zmineralizowanych } \\
\text { - zniszczenie słodkowodnych ekosystemów Bzury } \\
\text { i Moszczenicy, w tym obszaru NATURA } 2000 \\
\text { „Pradolina Bzury-Neru” } \\
\text { - emisja pyłowo-gazowa } \\
\text { - wykluczenie możliwości korzystania z innych } \\
\text { zasobów środowiskowych }\end{array}$ & $\begin{array}{l}\text { - wysiedlenie miejscowej ludności } \\
\text { - likwidacja sołectw znajdujących się w obrębie } \\
\text { kombinatu wydobywczo-energetycznego } \\
\text { - straty materialne wynikające z zasolenia wód } \\
\text { powierzchniowych i podziemnych w północnej } \\
\text { części województwa łódzkiego, stanowiących } \\
\text { bazę działalności gospodarczej dla niektórych } \\
\text { podmiotów gospodarczych (rozlewnie wód, } \\
\text { hodowle ryb) }\end{array}$ \\
\hline
\end{tabular}

Źródło: opracowanie własne.

Najwięcej korzyści zarówno środowiskowych, jak i społeczno-gospodarczych, przyniosłoby utworzenie w rejonie Rogóźna uzdrowiska wraz z elektrownią geotermalną (tab. 1A, B). Rozwój funkcji uzdrowiskowej oraz energetycznej (opartej na zasobach wód podziemnych oraz własnościach bryły solnej) umożliwiłby czerpanie korzyści z dwóch dóbr jednocześnie. Wykorzystanie komplementarnych zasobów energetycznych może przyczynić się do bardziej wydajnej pracy elektrowni geotermalnej. Jej utworzenie bardzo dobrze wpisywałoby się w ogólnoświatowy trend wykorzystywania odnawialnych źródeł energii oraz propagowania zasad zrównoważonego rozwoju. Zwłaszcza że w warunkach klimatycznych Polski środkowej może ona dostarczyć relatywnie dużo energii w porównaniu z innymi niekonwencjonalnymi źródłami. Ważnym aspektem związanym z działalnością uzdrowiska oraz geotermii jest możliwość dotychczasowego sposobu użytkowania ziemi na zasadniczej części „rejonu” Rogóźna. Problematyczne mogą być jedynie wielkopowierzchniowe fermy, negatywnie oddziałujące na jakość powietrza atmosferycznego. Realizacja tych koncepcji wiąże się jednak z dużymi nakładami finansowymi. Funkcjonowanie kompleksu uzdrowiskowo-rekreacyjnego przyczyni się do zwiększenia liczby osób przebywających w jego otoczeniu, co przełoży się na natężenie ruchu samochodowego, ilość wytwarzanych odpadów, ścieków, itp. Zasoby wód mineralnych, termalnych oraz leczniczych mogą okazać się zasobami nieodnawialnymi bądź bardzo trudno odnawialnymi. Zależne jest to od szeregu lokalnych czynników geologicznych oraz hydrogeologicznych. Dlatego bardzo ważne jest jak najdokładniejsze rozpoznanie zasobów, oszacowanie ich wielkości oraz określenie stopnia odnawialności. Od tych czynników zależeć może opłacalność powstania uzdrowiska i/lub geotermii.

Działalność kombinatu wydobywczo-energetycznego nie przyniesie żadnych korzyści środowiskowych (tab. 1C). Jego utworzenie spowoduje likwidację sołectw, wysiedlenie mieszkańców oraz przyczyni się do głębokich i nieodwracalnych zmian w krajobrazie. Rozwój funkcji energetycznej opartej na węglu brunatnym uniemożliwi prowadzenie jakiejkolwiek innej działalności w rejonie Rogóźna. Spowoduje także utratę możliwości czerpania korzyści z innych zasobów środowiskowych. 
Mnogość zasobów środowiskowych, mogących stanowić bazę rozwojową, skutkuje pojawieniem się wielu dylematów. Aby osiągnąć korzyści na skalę regionalną, należy dokonać ingerencji w skali lokalnej. Ważne jest, aby zadbać przy tym o jak najmniejsze straty środowiskowe oraz wkraczanie w sferę życia lokalnej społeczności. Wizja realnego (namacalnego) sukcesu lokalnego, przekładająca się na poprawę stanu i jakości życia mieszkańców, może przyczynić się do wygaszenia sytuacji konfliktowych.

\section{Literatura}

Badera J., 2010, Konflikty społeczne na tle środowiskowym zwiqzane z udostępnianiem złóż kopalin w Polsce, Gospodarka Surowcami Mineralnymi, 26, 1, s. 106-125.

Bald K., Krakowska E., Karski K., Piasecki B., Denecki J., Dutkiewicz P., 2011, Zmiana studium uwarunkowań i kierunków zagospodarowania przestrzennego Gminy Zgierz, Przedsiębiorstwo Zagospodarowania Miast i Osiedli „TEREN” Sp. z o.o.

Bański J., 2005, Sukces gospodarczy na obszarach wiejskich, Studia Obszarów Wiejskich, 8, s. 9-20.

Bański J., 2008, Wiejskie obszary sukcesu gospodarczego, Studia Obszarów Wiejskich, 14.

Bierkowska M., Błaszczyk J., 1989, Objaśnienia do mapy hydrogeologicznej Polski w skali 1:200 000, Państwowy Instytut Geologiczny, Warszawa.

Centrum Zrównoważonego Rozwoju, 2008, Geotermia wysadu solnego „Rogóźno”, Polska Energetyka Alternatywna, Łódź.

Cyran K., Garlicki A., 2008, Złoża soli kamiennej w Polsce i możliwości ich wykorzystania, [w:] M.J. Kotarba (red.), Przemiany środowiska naturalnego a rozwój zrównoważony, Wydawnictwo TBPŚ GEOSFERA, Kraków, s. 231-239.

Czapiewski K.t., 2010, Koncepcja wiejskich obszarów sukcesu społeczno-gospodarczego i ich rozpoznanie w województwie mazowieckim, Studia Obszarów Wiejskich, 22.

Czapowski G., Bukowski K., 2009, Złoża soli w Polsce - stan aktualny i perspektywy zagospodarowania, Przegląd Geologiczny, 57, 9, s. 798-811.

Decyzja Ministra Zdrowia z 19.04.2013r., Decyzja nr 70, MZ-OZU-520-31448-1/WS/13.

Dębski J., Podemski M., Szaniawski H., 1963, Dokumentacja geologiczna złoża soli kamiennej w wysadzie solnym Rogóźno, pow. Łęczyca, woj. Łódź, Państwowy Instytut Geologiczny, Warszawa.

Dmochowska-Dudek K., 2011, Obiekty NIMBY jako przykład konfliktowych inwestycji na terenach mieszkaniowych - teoretyczny zarys problemu, Space, Society, Economy, 10, s. 29-56.

Feltynowski M., 2009, Dostępność komunikacyjna jako element rozwoju gmin wiejskich Łódzkiego Obszaru Metropolitalnego, Infrastruktura i Ekologia Terenów Wiejskich, 6, s. 19-207.

Górecki M., 2013, Ocena stopnia zagrożenia użytkowych poziomów wodonośnych pomiędzy Zgierzem a Ozorkowem, Praca licencjacka, Łódź.

Górecki M., 2015, Chlorki jako wskaźnik geogenicznego zasolenia wód powierzchniowych i gruntowych na obszarze wysadu solnego Rogóźno, Praca magisterska, Łódź (praca w Repozytorium Ut: http://hdl.handle.net/11089/16858).

Górecki M., Ziułkiewicz M., 2016, The presence of geogenically saline waters in the area of salt dome Rogóźno (central Poland), Geology, Geophysics \& Environment, 42, 3, s. 289-310.

Herman K., Naramski M., Szromek A.R., 2014, Perspektywy powstania nowych uzdrowisk w Polsce, [w:] A.R. Szromek (red.), Rola uzdrowisk i przedsiębiorstw uzdrowiskowych w turystyce i w lecznictwie uzdrowiskowym, Proksenia, s. 109-126. 
Jabłońska B., 2006, Wpływ wód dołowych odprowadzanych z Kopalni Węgla Kamiennego „Ziemowit" na jakość wody w Potoku Goławieckim, Ochrona Środowiska, 3, s. 29-33.

Kasiński J.R., Czapowski G., Piwocki M., 2009, Rola halokinezy w powstawaniu trzeciorzędowych złóż węgla brunatnego na Niżu Polskim, Przegląd Geologiczny, 57, 11, s. 964-975.

Kasztelan A., 2010, Środowiskowa konkurencyjność regionów - próba konceptualizacji, Problemy Ekorozwoju, 5, 2, s. 77-86.

Kasztelewicz Z., Zajączkowski M., 2011, Analiza możliwości zagospodarowania złoża węgla brunatnego „Rogóźno" w kontekście zgazowania węgla, Polityka Energetyczna, 14, 2, s. 203-214.

Klatkowa H., 1993, Objaśnienia do Szczegółowej mapy geologicznej Polski 1:50 000, arkusz Zgierz, Instytut Geologiczny, Warszawa.

Kolago C., 1965, Perspektywy balneologiczne Łodzi, Przegląd Geologiczny, 13, 8, s. 350.

Krysiak S., 2014, Rola odłogów i terenów rekreacyjnych we współczesnych przemianach krajobrazów wiejskich regionu łódzkiego, Studia Obszarów Wiejskich, 35, s. 75-87.

Kucharski L., Kopeć D. (red.), 2014, Pradolina Bzury-Neru. Monografia przyrodnicza obszaru Natura 2000, Towarzystwo Przyrodników Ziemi Łódzkiej, Łódź.

Kucharski M., Krupa W.A., Ołdytowski T.G., 2013, Operat uzdrowiskowy obszaru ochrony uzdrowiskowej „Rogóźno” w gminie Zgierz, Izba Gospodarcza „Uzdrowiska Polskie”, Sopot.

Lewkiewicz-Małysa A., Winid B., 2005, Wybrane problemy zwiqzane z zagospodarowaniem wód kopalnianych, Wiertnictwo Nafta Gaz, 22, 1, s. 217-224.

Seweryn L., Górski G., Szczepanik P., Szczepiński J., 2004, Ochrona środowiska wodnego w rejonie kopalni Bełchatów przed wpływem wysadu solnego "Dębina” w aspekcie przyszłej eksploatacji złoża, Warsztaty z cyklu „Zagrożenia naturalne w górnictwie”, Materiały Sympozjum, s. 269-276.

Smętkiewicz K., 2014, Świadomość społeczna wykorzystania wód geotermalnych w województwie łódzkim i $w$ landzie Styria $w$ kontekście zrównoważonego rozwoju regionów, Wydawnictwo Ibidem, Łódź.

Stelmaszczyk Z., 1972, Ogólna charakterystyka hydrogeologiczna obszaru Rogóźna (praca magisterska), Archiwum Urzędu Marszałkowskiego Województwa Łódzkiego, Łódź.

Studium uwarunkowań i kierunków zagospodarowania przestrzennego gminy Zgierz, 1999, Przedsiębiorstwo Zagospodarowania Miast i Osiedli „TEREN” Sp. z o.o.

Tarka R., 1992, Tektonika wybranych złóż soli w Polsce na podstawie badań mezostrukturalnych, Prace Państwowego Instytutu Geologicznego, 137, Warszawa.

Tynenski Z., Właziński Z., Adamska T., Lesiewicz A., 2007, Analiza możliwości wykorzystania zasobów wód geotermalnych i powierzchniowych oraz borowin w okolicy miejscowości Rogóźno dla potrzeb rozwoju turystyki, rekreacji i lecznictwa, Centrum Zrównoważonego Rozwoju, Łódź.

Wójcik M., Dmochowska-Dudek K., Traczyk A., 2014, Konflikty społeczno-przestrzenne na obszarach wiejskich województwa łódzkiego, Biuletyn Krajowej Sieci Obszarów Wiejskich Województwa Łódzkiego, 4, s. 8-11.

https://bdl.stat.gov.pl/BDL/start (dostęp do strony: 27.03.2017r.)

https://bip.kprm.gov.pl/kpr/form/r1007, Projekt-rozporzadzenia-Rady-Ministrow-w-sprawienadania-statusu-obszaru-ochrony-.html (dostęp do strony: 8.01.2017r.)

http://lodzkie.naszemiasto.pl/artykul/kwb-adamow-zaczyna-ofensywe-o-zloza-wegla-w-rogoznie, 334732,art, t,id, tm.html (dostęp do strony: 27.03.2017r.)

http://lodzkie.naszemiasto.pl/artykul/samorzady-i-stowarzyszenia-przeciw-kopalni-w-rogoznie, 925433,art, t,id, tm.html (dostęp do strony: 27.03.2017r.) 


\section{Summary}

The article portrays the Rogóźno area which is located in the Zgierz district, to the north east of Łódź, as an area with potential towards economic success based on local environmental resources. These resources located in the northern part of the Zgierz district might serve as a developmental boost for both the Rogóźno area and the entire region. A multitude of resources, however, poses a threat of the emergence of conflicts. The use of the resources of the salt dome and waters: mineral, thermal and therapeutic is in opposition to the exploitation of lignite deposits. Low awareness of public opinion is reflected in the NIMBY syndrome in relations to planned investments. 